Wedgwood's Portrait Medallions of Men of Science

Is his Friday evening discourse before the Royal Institution on December 16, Dr. John Thomas spoke on "Josiah Wedgwood and his Portraits of Eighteenth Century Men of Science". The great success of three fellows of the Royal Society-Josiah Wedgwood and his two friends Matthew Boulton and James Watt-as industrialists was discussed. The successful production of artistic pottery at Etruria and of steam engines at Soho Factory, was only possible because of the persistent application of scientific principles. These 'philosophic' fellow. manufacturers endeavoured to satisfy this craving for scientific knowledge by attaching themselves to (a) the Lunar Society in the Midlands and (b) the Royal Society of London. Josiah Wedgwood, because of the artistic character of his jasper portrait medallions in the days before photography, established himself practically as the 'official' portrait producer of learned societies. Proof of this is the assembly of more than one hundred portrait medallions in Dr. Thomas's collection. Wedgwood handed the torch of science to his descendants, among whom was the illustrious Charles Darwin, his grandson, of whom Dr. Thomas exhibited a fine plaque by Wedgwood. Thus we, who live in the twentieth century, owe a great debt of gratitude to the 'prince of potters', not only for his scientific outlook, but also for the light which he has shed on his scientific contemporaries, through his inimitable portrait medallions.

\section{Earthquake in Spain}

AN earthquake was experienced in Spain on December 13, shaking the whole province of Valencia. The shock, which lasted three seconds, caused some apprehension and damaged buildings, but no casualties are reported. The district concerned is to some extent seismically active, as it borders the wellestablished Mediterranean region of earthquake activity, though it is not so densely populated with epicentres as is the region of Andalusia and Granada to the south of it. No really great earthquake has been experienced nearer to this region than Lisbon, 475 miles distant. It was from the Lisbon epicentre that the three shocks and several aftershocks occurred on and after November 1, 1755, at 9 h. $40 \mathrm{~m}$. local time. The first lasted seven minutes, destroyed Lisbon and caused remarkable sea-waves in such distant regions as Scotland and Sweden. The second at $10 \mathrm{~h}$. engulfed the Cays Depreda with the people on it and the vessels near it so that none of them were seen again, and altogether upwards of fifty thousand people lost their lives on that occasion.

\section{New Merseyside Nature Society}

Followne an inaugural field-meeting at Freshfield dunes and shore on December 11, a new nature study society for south-west Lancashire and Wirral was launched, as the Merseyside Branch of the British Empire Naturalists' Association, when the following officials were elected for 1939: Hon. President, $J$. W. Nixon (who is the Ribble Valley representative of the B.E.N.A. and honorary secretary of the Blackburn Naturalists' Field Club); Chairman, J. C. Miller, of the University of Liverpool; Hon. Organizing Secretary, Eric Hardy. It was announced that the new Merseyside Naturalists' Association would eover the area between the Ribble and the Dee on a much more modern and active method of general field nature study than was at present available in the area, although it was in no way antagonistic to some ten older natural history societies in the district. Mr. Hardy stated that the Society had been formed by about fifty naturalists and nature-lovers who had given their signatures to the desire for introducing the B.E.N.A. work to Merseyside. It was agreed that in 1939 they report on their area for the national bird survey being carried out by the scientific committee of the British Trust for Ornithology, and for the selected list of trees and insects chosen for national observation by the B.E.N.A. headquarters. Arrange. ments had been made for combination with the branches of the B.E.N.A. for Manchester and West Lancashire (Lytham).

\section{The Parliamentary Science Committee}

THE fifth annual meeting of the Parliamentary Science Committee was held at the House of Commons on December 13, under the presidency of Prof. J. Graham Kerr. The honorary secretary's report disclosed that the Committee's constituent bodies now number twenty-six, five of which have become affiliated during the past twelve months. Three peers and fourteen Members of Parliament are now associated with the executive, with the result that the Parliamentary activities of the Committee have greatly extended. Interventions in debate on the initiative of the Committee were frequent last session; more than thirty questions were asked in the House of Commons on scientific and technical matters; and during the current session it is hoped that members will be fortunate in the ballot for private members' motions. The Committee has been associated with Parliamentary action on the Thames barrage and the removal of the oil tanker limits on the Thames. Negotiations are on foot to establish complete liaison with the new Division for the Social and International Relations of Science of the British Association. Two lectures were arranged during the last session at the House of Commons for Members of Parliament. The following were elected officers for 1939 : President, the Right Hon. the Earl of Dudley; Vice-President, Sir Arnold Wilson, M.P.; Chairman, Mr. S. F. Markham, M.P. ; Vice-Chairman, Prof. B. W. Holman; Deputy-Chairman, Mr. Alan E. L. Chorlton, M.P.; and Hon. Secretary and Treasurer, Mr. H. W. J. Stone.

\section{The Cultural Influence of the Cinema}

The League of Nations Advisory Committee on Social Questions has issued a report, based on information collected from the Governments of forty-six countries and from other sources, on "The Recreational Cinema and the Young" (London: Allen and Unwin. Pp. 32. Price 9d.). It discusses the frequency of the attendance of young people at cinema theatres, the effects of attendance, juvenile taste in films, protection from unsuitable films, teaching of film 
appreciation, special performances and special films for juveniles. Of outstanding interest under the two last-mentioned headings are accounts of certain activities of the Governments of the U.S.S.R. Their "Children's Cinemas" are, it is said, equipped on broadly conceived lines as recreational centres. In addition to the theatre itself, they include a large hall for games and musical programmes, a library and reading room, a room for quiet table games, a refreshment counter, and a sort of cinema museum in which are displayed exhibits illustrating the history and technique of cinema production with sets of photographs of the best films and leading cinema personalities. Children are encouraged to amuse themselves, before the performance begins, in the various rooms, especially the large hall, where the programme usually is such as to prepare them for understanding the film about to be shown.

AParT from the technical staff of these Children's Cinomas, a special staff of teachers is employed in these houses. A special section of the Central Department for Industrial Cinematography employs a regular staff for the making of films for children, the subjects including travel and exploration, animal life, children of the U.S.S.R. and other countries, lives of remarkable persons and works of popular children's authors, among whom are mentioned Mark Twain, Jules Verne, Swift, Kipling and Pushkin. For the guidance of makers of such films certain basic principles have been prescribed, such as: "Any attempt to address children otherwise than in the real language of art, to 'talk down' to the child's intellectual level-i.e., any conscious or deliberate simplification-makes the juvenile film stereotyped and false. It should be simple with the simplicity of a real work of art, but not simplified".

\section{Technical Progress and Unemployment}

AN Advisory Committee on Management (International Labour Organization) at its meeting on May 2 and 3 studied the practical methols which industrial undertakings could adopt to alleviate the immediate social consequences of the elimination of surplus works or technical equipment and of the rapid and extensive mechanization of production (Geneva : International Labour Organization). The Committee drew up a list of measures which might be taken by organizations obliged to reduce their staff in consequence of progressive mechanization or other industrial changes. These measures are classified into five groups according to whether they are preliminary and designed to postpone or minimize or avoid dismissals as, for example, by reduction of hours or transfer of workers to other services; those intended to systematize inevitable dismissals, taking account of all psychological and moral issues involved; those intended to help workers who are dismissed; measures of adjustment among the remaining staff; and general measures involving co-operation with staff representatives, other undertakings and official or private organizations.
IN regard to the measures for dealing with actual dismissals, the Committee stresses the importance of selecting workers for dismissal on the basis of objective criteria, the information of staff in advance and the careful spreading of dismissals over a period. The Committee also considered a report prepared by the International Labour Office on the use of office machinery and its influence on conditions of work for staff. Various technical means of mitigating the physiological and.psychological consequences of the mechanization of office work were suggested by the Committee, which in regard to the general effects, expressed the opinion that a reduction of hours of work in offices would assist in reducing those drawbacks. The Committee also holds that to counteract the occupational consequences of the use of machines, the social guarantees recognized as due to the industrial worker should be granted equally to office employees, especially by a general extension of social legislation and of the system of collective agreements.

\section{The Rockefeller Foundation}

ThE Rockefeller Foundation in 1937 distributed a total of more than $\mathbf{9 , 5 0 0 , 0 0 0}$ dollars. Fifty-five per cent of the grants were for work in the United States, and among the largest appropriations and authorizations of the year were 420,000 dollars to the China Medical Board for the maintenance of the Peiping Union Medical College ; 360,000 dollars to Harvard University for research in industrial hazards; 300,000 dollars to the Yale University School of Medicine for the Department of Psychiatry; 300,000 dollars to the California Institute of Technology for the development of organic chemistry ; 275,000 dollars to the National Research Council for research in problems of sex and in biophysics; 250,000 dollars for the general research fund of the Yale University School of Medicine; 240,000 dollars to the Royal Institute of International Affairs for research in international problems ; 156,000 dollars for teaching and research in psychiatry at the Harvard Medical School and Massachusetts General Hospital ; 150,000 dollars to the National Institute of Economic and Social Research for basic economic research, and 100,000 dollars to the International Institute of Intellectual Co-operation for research in connexion with the International Studies Conference. The annual report of the Foundation includes the president's review with the detailed reports of the secretary, the treasurer and the directors of the International Health Division, the Medical Sciences, the Natural Sciences, the Social Sciences and the Humanities and the vice-president in charge of the programme in China.

IN the natural sciences, the Foundation has given its major support to experimental biology, including research on hormones, nutrition, and enzyme chemistry, while assistance given to organic chemistry has been largely prompted by a desire to develop work on its biological aspects with the view of forwarding the progress of medicine itself in the United States. The president's remarks on the social sciences are of 